\title{
Estimating future runoff levels for a semi-arid fluvial system in central Arizona, USA
}

\author{
Andrew W. Ellis ${ }^{1, *}$, Timothy W. Hawkins ${ }^{2}$, Robert C. Balling Jr. ${ }^{1}$, Patricia Gober ${ }^{1}$ \\ ${ }^{1}$ School of Geographical Sciences, Arizona State University, Tempe, Arizona 85287-0104, USA \\ ${ }^{2}$ Department of Geography and Earth Science, Shippensburg University, Shippensburg, Pennsylvania 17257, USA
}

\begin{abstract}
We developed a water budget runoff model for the Salt and Verde River basins of central Arizona and used the outputs of 6 global climate models (GCMs) to estimate runoff in the future under assorted emissions scenarios developed by the Intergovernmental Panel on Climate Change (IPCC). We used a statistical downscaling routine to refine the GCM outputs for the 2 basins, and we found that all model-scenario combinations simulate a mean temperature rise in the study area of between 2.4 and $5.6^{\circ} \mathrm{C}$, using year 2050 greenhouse gas concentrations. Mean changes in precipitation vary substantially among the models and scenarios, and, as a result, changes in runoff vary from 50 to $127 \%$ of historical levels. Assuming equal probabilities associated with each scenario and model run, the overall results suggest that runoff from the Salt and Verde will have an approximately $85 \%$ chance of being less strong, the certainty of which is related to consensus on warming in the study area. The large variability among predictions of precipitation trends introduces substantial uncertainty.
\end{abstract}

KEY WORDS: Dryland runoff $\cdot$ Climate change $\cdot$ Water budget

\section{INTRODUCTION}

Global climate change may reveal itself in a number of ways across local and regional scales. As an example, global climate models (GCMs) generally predict that precipitation levels will increase at hemispheric and global scales, but the same models predict that some areas of the earth will receive less precipitation in the future (IPCC 2007). However, from model to model, the results vary considerably in their simulations of future conditions at local and regional scales, and policymakers must cope with substantial uncertainty as they plan for the future.

Uncertainty in the local impacts of global climate change raises concern about continued population growth and the economic development of central Arizona. The rapidly growing desert city of Phoenix depends heavily upon faraway sources of water from the Colorado River Basin through the Central Arizona Project and from the upland watersheds of the Salt and Verde Rivers (Gammage 1999, Gober 2005). To account for the extreme variability of their desert cli- mate, Phoenix's early leaders constructed one of the world's largest and most sophisticated water storage and delivery systems on the planet, and developed a set of regulations and agreements to allocate water. These water agreements and the physical infrastructure have assured an adequate water supply for the region's current population of 4 million, and they are the basis for projections of some 8 million residents by 2040 (Jacobs \& Holway 2004, Arizona Department of Economic Security 2006).

Uncertainties associated with climate change create several challenges for water managers, planners, and decision makers in Phoenix. First, changes in climatic conditions on the watersheds can alter runoff regimes, affect water supply, and jeopardize growth in a city whose economy is heavily dependent upon land development and housing construction. Second, the sheer magnitude of growth $(>100000$ new residents are added annually), in conjunction with natural climate variability, and anthropogenic climate change raises the stakes that the region will overshoot its sustainable population before the regional impacts of climate 
change are fully known. And third, if future climate conditions differ substantially from historical conditions, then the political institutions that have allocated water so effectively in the past will need to be reconsidered and revised. Real reductions in water supply, or even the possibility of reductions, will force decision makers to confront previously taboo subjects such as the efficacy of decades-old water pacts and regulations, pricing schemes that rise rapidly after basic needs are met, restrictions on landscaping treatments, and density and growth management.

During the last $25 \mathrm{yr}$ there have been at least 6 major studies of the potential impacts of future climate change on runoff within the Colorado River Basin, and all suggest a trend to less runoff in the future. Revelle \& Waggoner (1983) used the simple approach of applying temperature and precipitation scenarios for the Upper Basin to a statistical regression equation relating the variables to runoff. Nash \& Gleick $(1991,1993)$ used temperature and precipitation scenarios and more sophisticated GCM output under doubled atmospheric concentrations of $\mathrm{CO}_{2}$ to run a National Weather Service hydrology model for the Upper Basin. Christensen et al. (2004) used National Center for Atmospheric Research (NCAR) GCM output from a 'business as usual' (BAU) gas emissions scenario as input to the variable infiltration capacity (VIC) hydrological model across the entire Colorado River Basin. Hoerling \& Eisched (2007) applied multiple GCM outputs under BAU emissions to the calculation of the Palmer drought severity index (PDSI), which was related to runoff in the upper Colorado Basin using statistical regression. Most recently, Christensen \& Lettenmaier (2006) used multiple GCM outputs for 2 emissions scenarios to alter temperature and precipitation inputs to the VIC model that was run for the entire Colorado River Basin. Each of these studies signaled a likelihood of significant reductions in runoff within the basin in response to warmer and drier conditions, particularly during winter months. Like these studies, we were interested in the potential changes in runoff in response to future climate change.

In this investigation, we estimated average runoff levels and the degree of uncertainty for the combined Salt and Verde River systems of Arizona using mean climate conditions generated by GCMs operating under different global emissions scenarios for 2050 . We constructed a runoff model for the basins, and verified it with historical data. We then downscaled GCM outputs to the Salt and Verde, and altered the runoff model based on the downscaled results. We used 6 different climate models and 9 future scenarios from the IPCC's (Intergovernmental Panel on Climate Change) 'Special Report on Emissions Scenarios' (Nakicenovic \& Swart 2000) in an attempt to estimate uncertainties in the runoff estimates. Unlike the previous studies of the past $25 \mathrm{yr}$, we focused on the 2 specific watersheds in the lower Colorado River Basin that represent a critical portion of the water supply of growing metropoli$\tan$ Phoenix. The warm and arid climate of this area is considerably different from that of the Upper Basin, where many of the previous studies have been focused. Due to the relatively small size of the 2 watersheds, we used a greater spatial resolution than those used in the methodologies of the previous studies. Unlike the previous studies, we apply a broad range of GCM-emission scenario combinations to provide a greater understanding of the uncertainty of future conditions. We believe that the results will prove useful to policymakers who must not only plan for millions of new residents in the Phoenix area in coming decades, but also consider possible reductions in surface water supply.

\section{STUDY AREA}

The upland Salt and Verde watersheds (Fig. 1a) together represent 1 of 3 major sources of water for the Phoenix region, the other 2 being groundwater and Colorado River water. In providing approximately $40 \%$ of the water supply to metropolitan Phoenix, runoff on the 2 watersheds is collected by a series of 6 dams (Fig. 1b) and stored in lake reservoirs. The reservoirs within the Salt-Verde system have a combined storage capacity of approximately 2.8 billion $\mathrm{m}^{3}$, with the Salt system accounting for nearly $88 \%$ of the combined capacity. Annually, the Salt-Verde system delivers $>1.2$ billion $\mathrm{m}^{3}$ of water to downstream users.

The Salt and Verde watersheds form an area of approximately $33800 \mathrm{~km}^{2}$ of complex topography and are generally at a much greater elevation than that of the greater Phoenix area (Fig. 1b). Winter precipitation, including snowfall, is the critical factor in the variability of water yield from the Salt-Verde system. Precipitation amounts are relatively high for the longest sustained period during the winter season, when atmospheric demand (potential evapotranspiration, PE) is low (Table 1). For the 2 systems combined, $30 \%$ of annual precipitation occurs during January through March compared to $37 \%$ during the monsoon season of July through September. However, $58 \%$ of annual total PE occurs during the summer months compared to only $5 \%$ during the winter months, making monsoon season precipitation relatively unimportant from a water resources standpoint (Table 1).

Mean annual runoff on the Salt watershed is $61 \%$ of the total runoff from the 2 watersheds combined. Runoff on both watersheds peaks in March as a result of the cool wet winter and early spring snowmelt 

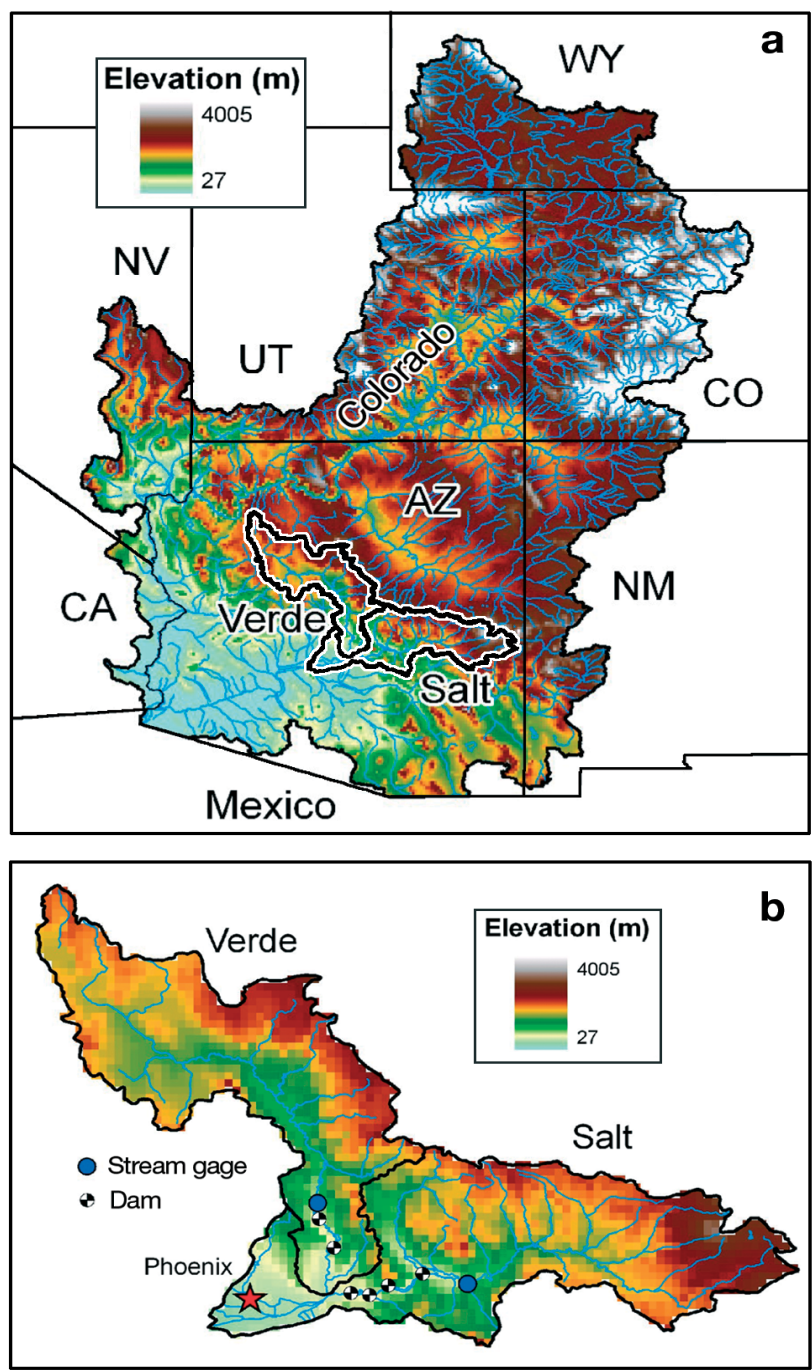

Fig. 1. (a) The Colorado River Basin and the Salt and Verde watersheds (US state abbreviations are given). (b) Details of the Salt and Verde watersheds
(Table 1). During the months January through March combined runoff from the 2 systems represents $46 \%$ of the annual total, while only $12 \%$ of the annual total is generated during the summer months of July through September. A product of their close proximity is the fact that runoff on the 2 watersheds is highly correlated $(\mathrm{r}=0.92)$.

\section{METHODS}

\subsection{Estimation of monthly runoff}

We developed a monthly water budget model using the Thornthwaite-Mather climatic water budget (CWB) model as a guide (Thornthwaite \& Mather 1955). Our model combines a solution for evapotranspiration with measured precipitation and soil moisture capacity to simulate root zone soil moisture content and associated surplus or deficit of water. As with the CWB model, our model requires inputs of mean monthly temperature, total precipitation, soil moisture capacity, and latitude (discussed below). Our use of a monthly water budget approach to modeling runoff from the Salt and Verde watersheds stems from the lack of a dense network of long-record hourly and daily meteorological stations within the study area that would be necessary for accurate calculation of daily soil moisture and integration to monthly values. Across the nearly $34000 \mathrm{~km}^{2}$ of the watersheds there are 20 United States National Weather Service cooperative observing (daily) stations and 29 stations with at least hourly data from a number of networks. The greater issue, particularly with the stations of finer temporal resolution, is that most of the stations possess a record length of only about $20 \mathrm{yr}$, whereas the monthly dataset used in this study extends back in time to January 1895.
Table 1. Mean monthly values of air temperature $\left(T_{\mathrm{a}},{ }^{\circ} \mathrm{C}\right)$, precipitation $\left(P_{\mathrm{r}}, \mathrm{mm}\right)$, potential evapotranspiration $(\mathrm{PE}, \mathrm{mm})$, runoff (RO, millions of cubic meters), and reservoir storage (ST, millions of cubic meters) for the Salt (S) and Verde (V) watersheds

\begin{tabular}{|c|c|c|c|c|c|c|c|c|c|c|}
\hline & \multicolumn{2}{|c|}{$T_{\mathrm{a}}$} & \multicolumn{2}{|c|}{$P_{\mathrm{r}}$} & \multicolumn{2}{|c|}{ PE } & \multicolumn{2}{|c|}{ RO } & \multicolumn{2}{|c|}{ ST } \\
\hline & S & $\mathrm{V}$ & $\mathrm{S}$ & $\mathrm{V}$ & $\mathrm{S}$ & V & $\mathrm{S}$ & V & S & V \\
\hline Jan & 1.1 & 2.2 & 54.6 & 46.9 & 4.6 & 5.8 & 81.0 & 61.7 & 1118.2 & 132.2 \\
\hline Feb & 2.8 & 3.9 & 48.5 & 47.2 & 8.3 & 10.0 & 94.2 & 80.0 & 1175.2 & 154.4 \\
\hline Mar & 5.2 & 6.2 & 51.8 & 43.8 & 19.2 & 21.3 & 151.4 & 114.1 & 1250.4 & 174.8 \\
\hline Apr & 9.1 & 9.8 & 25.6 & 26.8 & 40.7 & 41.8 & 144.6 & 60.9 & 1363.7 & 207.3 \\
\hline May & 13.4 & 14.1 & 12.9 & 11.9 & 72.9 & 73.9 & 77.1 & 15.9 & 1418.1 & 213.2 \\
\hline Jun & 18.4 & 19.3 & 13.7 & 9.4 & 107.2 & 110.3 & 26.4 & 9.6 & 1387.5 & 192.0 \\
\hline Jul & 21.0 & 22.5 & 74.4 & 53.9 & 128.6 & 136.3 & 24.7 & 13.2 & 1301.9 & 160.4 \\
\hline Aug & 20.1 & 21.5 & 85.6 & 65.9 & 114.3 & 120.7 & 43.7 & 23.9 & 1208.6 & 131.4 \\
\hline Sep & 17.3 & 18.4 & 47.3 & 39.2 & 84.6 & 87.5 & 33.2 & 20.4 & 1153.0 & 123.2 \\
\hline Oct & 11.6 & 12.7 & 39.3 & 31.9 & 49.5 & 51.5 & 32.2 & 24.2 & 1096.3 & 121.3 \\
\hline Nov & 5.7 & 6.7 & 38.7 & 31.6 & 17.5 & 19.7 & 28.0 & 26.3 & 1085.4 & 118.3 \\
\hline Dec & 1.7 & 2.7 & 50.3 & 42.3 & 5.4 & 6.8 & 56.5 & 52.7 & 1097.9 & 119.2 \\
\hline
\end{tabular}

\subsection{Input data and model resolution}

Mean monthly temperature, monthly total precipitation, field capacity of the soil, and latitude are the only input requirements for our water budget model. The parameter-elevation regressions on independent slopes model (PRISM) dataset (Daly et al. 1994) was used to provide historic (1895 to 2005) mean monthly temperature and total precipitation inputs (www.prism. oregonstate.edu/). The resolution of the PRISM grid is $0.0416^{\circ}$ of latitude and longitude (approximately $4 \mathrm{~km}$ ). The water budget model that we created 
was distributed to generate monthly runoff from each of 1485 grid cells that drain to the most downstream gage measuring unregulated flow within the Salt and Verde basins (Fig. 1b).

The field capacity (FC) of the soil across the watersheds, or the ability of the soil to hold moisture against gravity due to capillary forces, was determined using the available water capacity (AWC) and soil texture class fields from The Pennsylvania State University (PSU) Soil Information for Environmental Modeling Ecosystem Management database (www.soilinfo.psu. edu) (Miller \& White 1998). This database was derived from the State Soil Geographic (STATSGO) database of the National Resources Conservation Service (NRCS). The PSU data are presented as geographic polygons and thus were re-sampled to align with the PRISM grid. Since FC values are not contained in the PSU database, AWC values were modified using the soil texture class (Fig. 2a) and the properties associated with these classes (Table 2). AWC represents the difference between FC and the permanent wilting point (PWP) and thus does not represent the true water holding capacity of the soil. AWC along with soil texture does, however, provide the necessary information to determine FC.
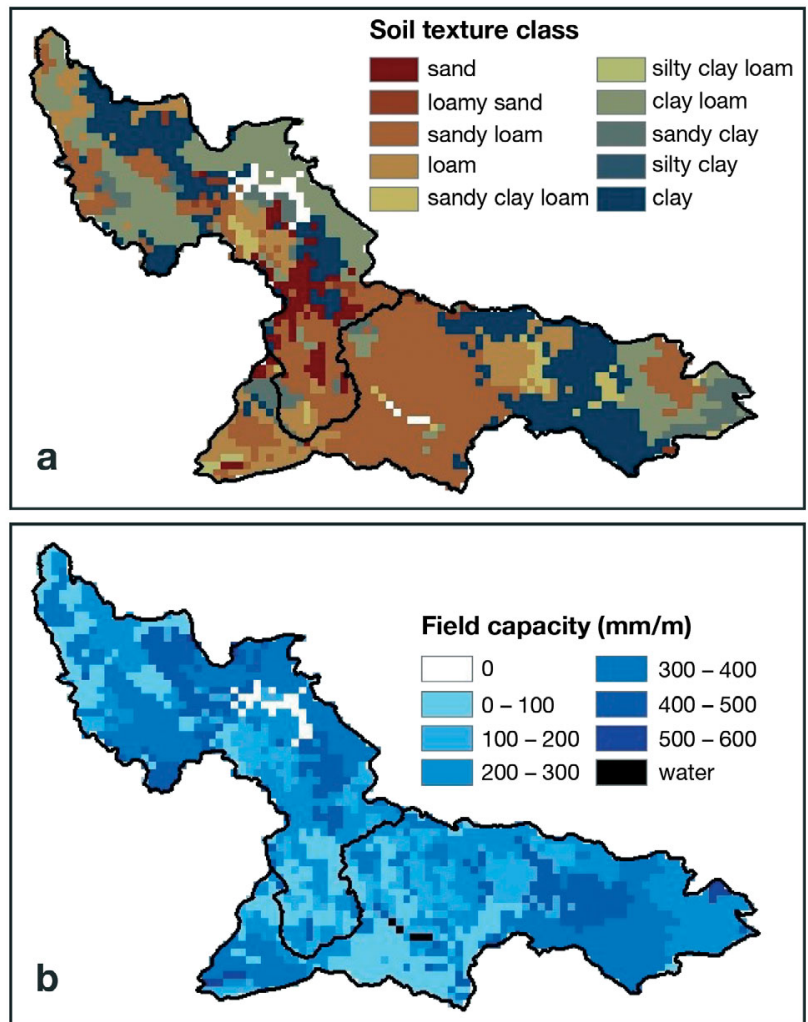

Fig. 2. (a) Soil texture classes for the Salt and Verde watersheds, where white pixels represent bedrock for the Verde and water for the Salt, and (b) field capacity for soils on the Salt and Verde watersheds
For each soil class, the ratio AWC/FC was calculated using the low value of the AWC range and the high value of the FC range (Table 2). For each grid cell on the Salt and Verde watersheds, the AWC value for the cell was divided by the appropriate ratio as determined by the soil texture for that cell to yield a FC value for the cell.

A variety of $\mathrm{AWC} / \mathrm{FC}$ ratios were calculated for the soil texture classes based on the ranges of AWC and FC. The ratios displayed in Table 2 represent values that produced the most accurate stream flow simulations. Furthermore, the FC values that resulted from these ratios seem to make physical sense. The average FC for the Salt and Verde watersheds using these ratios was $224 \mathrm{~mm} \mathrm{~m}^{-1}$. If the average FC values presented in Table 2 were assumed for each grid cell based on the soil texture class for that cell, the resulting basin-wide FC would be $276 \mathrm{~mm} \mathrm{~m}^{-1}$. Thus, the method we employed yielded results that were comparable to a more generic calculation. Furthermore, this method also included many of the intricacies associated with the STATSGO database and seems to produce a reasonable estimate of soil moisture storage capacity.

The active soil moisture storage layer was defined as $1.0 \mathrm{~m}$ for the Salt and $1.5 \mathrm{~m}$ for the Verde, which for most cells on the watersheds represents the depth to bedrock. Many crops and most trees have rooting depths $>1.5 \mathrm{~m}$ (Allen et al. 1998), and the strong evaporative demand for soil moisture in the arid southwestern United States suggests that 1.0 and $1.5 \mathrm{~m}$ are reasonable depths from which evapotranspiration can occur. Other hydrologic models use active soil moisture storage depths equal to or greater than the depths modeled here. The Climate Prediction Center (CPC) soil moisture model uses a storage depth of $1.6 \mathrm{~m}$ (Huang et al. 1996), and the University of Washington

Table 2. Soil properties for various texture classes found on the Salt and Verde watersheds derived from Allen et al. (1998). Properties were not given for classes marked with an asterisk, but were estimated from other classes. FC: field capacity; AWC: available water capacity

\begin{tabular}{|lrrr|}
\hline Texture class & $\begin{array}{c}\mathrm{FC} \\
\left(\mathrm{mm} \mathrm{m}^{-1}\right)\end{array}$ & $\begin{array}{c}\text { AWC } \\
\left(\mathrm{mm} \mathrm{m}^{-1}\right)\end{array}$ & Ratio \\
\hline Sand & $70-170$ & $50-110$ & 0.29 \\
Loamy sand & $110-190$ & $60-120$ & 0.32 \\
Sandy loam & $180-280$ & $110-150$ & 0.39 \\
Loam & $200-300$ & $130-180$ & 0.43 \\
Sandy clay loam* & $220-360$ & $130-190$ & 0.36 \\
Silty clay loam & $300-370$ & $130-180$ & 0.35 \\
Clay loam* & $260-350$ & $130-190$ & 0.36 \\
Sandy clay* & $270-380$ & $130-200$ & 0.33 \\
Silty clay & $300-420$ & $130-190$ & 0.31 \\
Clay & $320-400$ & $120-200$ & 0.30 \\
\hline
\end{tabular}


variable infiltration capacity (UW VIC) model (Liang et al. 1994, Wood \& Lettenmaier 2006) uses the same PSU data as the model presented here, with a storage depth down to bedrock.

\subsection{Estimation of potential evapotranspiration}

The basis of any water budget model is the simulation of $\mathrm{PE}$, and we tested several temperature-based methods for estimating monthly PE (Thornthwaite \& Mather 1955, Blaney \& Criddle 1950, Hamon 1961, Kharrufa 1985). We compared monthly PE estimates from each method with monthly sums of daily PE calculated using the more data-intensive Penman method. Daily Penman PE data were obtained from 2 Arizona meteorological network stations (AZMET; http://ag.arizona.edu/azmet/) and 3 stations from the Bureau of Land Management Remote Area Weather Stations (RAWS; www.raws.dri.edu) that are located on the Salt and Verde watersheds. We also employed each method of PE calculation in our final water budget model and verified the simulated runoff on the watersheds with observed values. The Hamon (1961) method produced the best results across all seasons, especially when applying a calibration coefficient of 1.2 following Federer \& Lash (1983), Sun et al. (2002), and $\mathrm{Lu}$ et al. (2005). The Hamon equation for PE $\left(\mathrm{mm} \mathrm{mo}^{-1}\right)$ is:

$$
\mathrm{PE}=13.97 d D^{2} W_{t}
$$

where $d$ is the number of days in a month, $D$ is the mean monthly hours of daylight in units of $12 \mathrm{~h}$, and $W_{t}$ is a saturated water vapor density term, which is calculated as

$$
W_{t}=\frac{4.95 \mathrm{e}^{0.062 T}}{100}
$$

where $T$ is mean monthly temperature $\left({ }^{\circ} \mathrm{C}\right.$ ) (Wolock \& McCabe 1999). The Hamon method has been tested and used in many research applications (e.g. Federer \& Lash 1983, Federer et al. 1996, Wolock \& McCabe 1999, Xu \& Singh 2001, Sun et al. 2002, Legates \& McCabe 2005, Lu et al. 2005).

\subsection{Estimation of monthly soil moisture}

Following the popular method initially put forward by Thornthwaite \& Mather (1955), actual evapotranspiration (AE) within our water budget model is simply calculated as a fraction of $\mathrm{PE}$, where the $\mathrm{AE} / \mathrm{PE}$ ratio equals the ratio of soil moisture to $\mathrm{FC}$. As soil moisture declines linearly, so does the atmosphere's ability to extract moisture through evapotranspiration.
The original CWB model contained only a single reservoir in the form of the root zone of the soil. Snow pack is an important reservoir for simulating the timing of runoff on the Salt and Verde watersheds, where winter and early spring snow pack ultimately represent a significant amount of the peak springtime runoff. Willmott et al. (1985) produced a snow accumulation function for the CWB based on a temperature threshold of $-1^{\circ} \mathrm{C}$, whereby all precipitation in a given month is snowfall if the mean monthly temperature is below the threshold. For our water budget model we chose to use daily precipitation, daily snowfall water equivalent, and mean monthly air temperature data from 12 Snowpack Telemetry (SNOTEL; www.wcc.nrcs.usda.gov/snotel/) stations (see Serreze et al. 1999 for a good description) within and around the Salt and Verde watersheds to develop a function that estimates the fraction of monthly precipitation $(P)$ falling as snow $\left(P_{\mathrm{s}}\right)$. We used pairs of observations of mean monthly temperature and the ratio of liquid precipitation falling as snow to total liquid precipitation during October through May, 1983 to 2006, for the 12 stations to produce a simple linear regression equation for estimating the $P_{\mathrm{s}} / P$ ratio. The equation was developed using only data from months possessing $>3 \mathrm{~d}$ of precipitation (i.e. $>1$ synoptic-scale storm). The equation is:

$$
\frac{P_{\mathrm{s}}}{P}=0.47-0.04 T
$$

The regression equation explains $37 \%$ of the variance in 1658 monthly $P_{\mathrm{s}} / P$ ratios.

Similarly, using data from the 12 SNOTEL stations, we paired observations of mean monthly temperature and monthly totals of daily snow water equivalent (SWE) loss during months with continuous snow cover to produce regression equations for snow melt $(M)$. Considering that the variation in solar radiation through the fall, winter, and spring seasons likely plays a variable role in snow melt relative to monthly air temperature, we developed melt equations for each month of January through March and for December or earlier and April or later. The multimonth time periods at the beginning and end of the season were adopted in order to increase the $n$ size for these shoulder periods for which month-long continuous snow cover is rarer. Quadratic equations produced the best results for the fall and spring seasons, while cubic equations worked best in January and February. For example, the January melt $\left(M_{;} \mathrm{mm}\right)$ equation is:

$$
M=15.46+2.25 T+0.25 T^{2}+0.03 T^{3}
$$

The equations explained a broad range of variance in melt, from only $11 \%$ in December or earlier $(n=189)$, 
to $42 \%$ in February ( $\mathrm{n}=214$ ), and lowering to $33 \%$ in April or later $(n=29)$. It should be noted that the snow accumulation and melt functions mostly act to alter the timing of runoff and not the amount.

There is no way to determine the portion of SWE lost to sublimation through SNOTEL data, but it is assumed to be very small compared to snowmelt. Within the water budget model, melt values were constrained so that they could not exceed the SWE value for that month. Values of SWE (mm) for the current month, $i$, were calculated as:

$$
\mathrm{SWE}_{i}=\mathrm{SWE}_{i-1}+P_{\mathrm{s}}-M
$$

where $P_{\mathrm{s}}$ is the amount of snowfall for the current month as determined by Eq. (3).

While these methodologies for determining monthly snowmelt and SWE, and differentiating rainfall from snowfall on a monthly basis, are simplistic and do not account for daily temperature changes, energy fluxes, or synoptic and mesoscale atmospheric circulations, the methodologies keep data requirements to a minimum and work satisfactorily based on comparisons of measured SWE at the SNOTEL stations and modeled SWE for the PRISM grid cell containing each station (Fig. 3, Table 3). Model evaluation statistics indicate reasonable agreement between observed and predicted values of SWE (Table 3), especially for the December through March period. Correlation coefficients (r) were calculated to assess the co-variability of the modeled and observed values, while Willmott's index of agreement $(D)$ (Willmott 1982) was used to assess the similarity of the values, representing not just the covariance, but the relative magnitudes as well. A $D$-statistic value of unity indicates that the 2 sets of values are identical, while a value of zero indicates no agreement. The best predicted-observed agreement

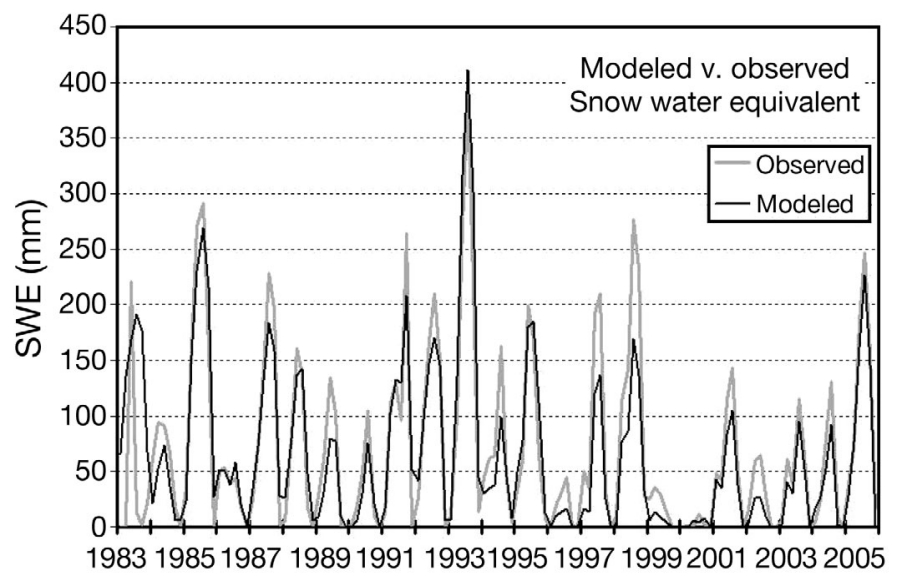

Fig. 3. Mean values of monthly modeled and observed snow water equivalent (SWE, mm) for the 12 SNOTEL stations. Time series for each year: November through April (of following year) is in mid-winter (January and February), while the accuracy lessens toward spring and fall (Table 3). The general under-prediction of SWE is visually evident when comparing the time series of monthly modeled and observed values (Fig. 3). This means that a greater fraction of precipitation in the model is rainfall than is actually the case, which would produce an earlier timing of the runoff than is actually observed. However, it is likely that a portion of the inconsistency stems from the comparison of actual station data (SNOTEL) with data modeled for a PRISM grid cell containing each SNOTEL station. In addition to the problem of comparing observed values for a point location with modeled values for a $16 \mathrm{~km}^{2}$ area, the model uses PRISMgenerated precipitation values, which may fall short of the actual precipitation occurring at the high-elevation SNOTEL stations.

We are concerned about how well the regression equations for snow accumulation and melt apply to potential future climate conditions. Although they are likely not entirely time invariant, we make the assumption that the basic relationships between air temperature and snowfall and snow melt will hold through the middle of the 21st century. Furthermore, as noted earlier, when we ran the water budget model with and without functions for snow accumulation and melt, it became apparent that the snow functions basically act to alter the timing of runoff and not the amount.

Within the water budget model a monthly adjusted value of precipitation $\left(P_{\mathrm{a}}, \mathrm{mm}\right)$ was calculated as:

$$
P_{\mathrm{a}}=P_{\mathrm{r}}+M
$$

where $P_{\mathrm{r}}$ is the amount of precipitation in the form of rainfall determined by Eq. (3).

\subsection{Estimation of monthly surplus water}

During months when soil moisture reaches or is at capacity, excess water, or surplus $(S, \mathrm{~mm})$, is simply calculated as:

$$
S=P_{\mathrm{a}}-\mathrm{PE}-R
$$

where $R$ is the amount of moisture needed to recharge the soil to capacity. The monthly surplus value for each cell that drains to the discharge point of each basin was multiplied by the area of the cell to create a volume of water. The volumes of water from all cells draining to the discharge point for each watershed were summed to produce a monthly total volume of excess water on the Salt and Verde watersheds. Our water budget model is not a sophisticated hydrologic model and therefore cannot handle the complex path of surplus water from point of generation to the stream gage. Since there are no established parameters for the frac- 
Table 3. Mean model evaluation statistics for the monthly snow water equivalent (SWE) using observed (O) data from the 12 SNOTEL stations and predicted (P) data for the grid cell containing each of the stations. Included are the mean $(\mathrm{Mn})$, standard deviation (SD), correlation coefficient (r), index of agreement $(D)$, and mean absolute error (MAE)

\begin{tabular}{|lrrrrrrrr|}
\hline & $\begin{array}{c}\text { Stations } \\
(\mathrm{n})\end{array}$ & $\begin{array}{c}\text { Mn_P } \\
(\mathrm{mm})\end{array}$ & $\begin{array}{r}\mathrm{Mn} \\
(\mathrm{mm})\end{array}$ & $\begin{array}{r}\text { SD_P } \\
(\mathrm{mm})\end{array}$ & $\begin{array}{r}\text { SD_O } \\
(\mathrm{mm})\end{array}$ & $\mathrm{r}$ & $D$ & $\begin{array}{l}\text { MAE } \\
(\mathrm{mm})\end{array}$ \\
\hline Nov & 12 & 22.2 & 23.4 & 24.9 & 25.9 & 0.32 & 0.54 & 23.3 \\
Dec & 12 & 61.0 & 64.9 & 50.3 & 47.2 & 0.53 & 0.67 & 41.1 \\
Jan & 12 & 101.0 & 125.6 & 84.8 & 86.6 & 0.81 & 0.81 & 56.5 \\
Feb & 12 & 125.8 & 149.8 & 103.9 & 113.2 & 0.73 & 0.77 & 79.9 \\
Mar & 11 & 79.6 & 92.9 & 98.8 & 111.0 & 0.61 & 0.67 & 78.1 \\
Apr & 4 & 18.6 & 17.9 & 42.4 & 38.2 & 0.57 & 0.42 & 30.5 \\
\hline
\end{tabular}

tion of excess water on the Salt and Verde watersheds that goes into recharging aquifers rather than runoff, we assumed that all excess water moves through the discharge point for each basin.

\subsection{Estimation of monthly runoff}

Within the CWB (Thornthwaite \& Mather 1955, Mather 1978) surplus soil moisture is translated to runoff by making the assumption that a portion of the surplus water appears at the discharge point of the watershed during the current month, while the remainder lags and appears in subsequent months. The basic recommendation by Thornthwaite \& Mather (1955) is to halve the monthly surplus such that one-half runs off in the current month and the other one-half is added to the surplus water of the subsequent month. However, Mather (1978) suggests testing runoff-carry over combinations to find the best fit for the specific watershed being studied and illustrates the appropriateness of a runoff-carry over combination of 80 to $20 \%$ for one particular watershed. We tested different runoff-carry over combinations and found that 75 to $25 \%$ outside of the summer monsoon season (October through June) and 90 to $10 \%$ during the monsoon season (July through September) verified the best.

\section{MODEL PERFORMANCE}

Stream flow data from the United States Geological Survey gage just above the dam-controlled portion of each watershed (Fig. 1b) were used to assess the performance of the water budget model in simulating runoff through 2005 (http://waterdata.usgs.gov/az/ nwis). The record for the Salt River (Gage ID 9498500) begins in 1914 and that for the Verde River (Gage ID 9508500) begins in 1946. Simulation of runoff on the more productive Salt watershed is much better than on the drier and warmer Verde watershed (Fig. 4, Table 4). Intra-annual variability in runoff on the Salt is simulated rather well by the water budget model, while the small peak in runoff in summer on the Verde is not captured (Table 4). In general, the model has a tendency to predict too much runoff during spring and early summer and too little during the summer monsoon season. The variability in monthly runoff is generally too large in winter and too small during the monsoon season. We expected the model to represent too much runoff in spring, since the water budget model does not account for water lost to aquifers and pumping, especially on the more populated Verde watershed. Under-prediction of runoff during the summer monsoon season may, in part, stem from error associated with the creation of gridded precipitation fields (PRISM) using station data that will not represent the patchy warm season convective precipitation as well as the more spatially homogeneous precipitation of winter. Additionally, the monthly resolution makes it

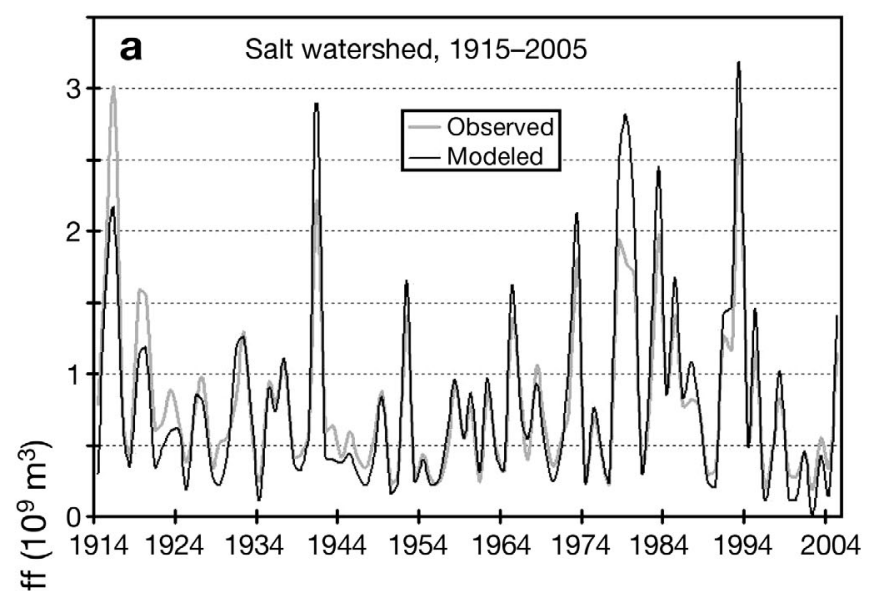

$\stackrel{5}{5}$

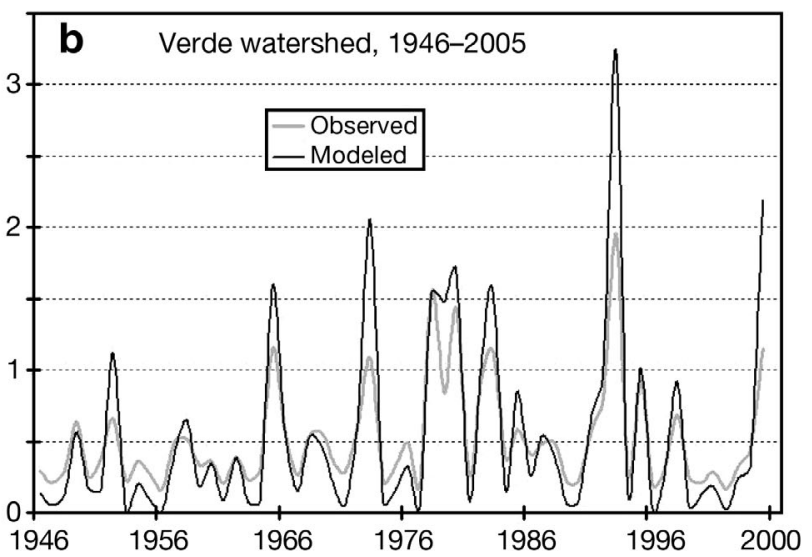

Fig. 4. Modeled and observed values of annual runoff 
Table 4. Model evaluation statistics for monthly and annual runoff using observed $(\mathrm{O})$ data from United States Geological Survey stream flow gages and predicted $(\mathrm{P})$ data from the water budget model. Included are the mean $(\mathrm{Mn})$, standard deviation (SD), correlation coefficient (r), index of agreement $(D)$, and mean absolute error (MAE)

\begin{tabular}{|c|c|c|c|c|c|c|c|}
\hline & $\begin{array}{l}\text { Mn_P } \\
\text { (million }\end{array}$ & $\begin{array}{l}\text { Mn_O } \\
\text { (s of } \mathrm{m}^{3} \text { ) }\end{array}$ & $\begin{array}{l}\text { SD_P } \\
\text { (millio }\end{array}$ & $\begin{array}{l}\text { SD_O } \\
\text { is of } \mathrm{m}^{3} \text { ) }\end{array}$ & $\mathrm{r}$ & $D$ & $\begin{array}{c}\text { MAE } \\
\text { (millions of } \mathrm{m}^{3} \text { ) }\end{array}$ \\
\hline \multicolumn{8}{|c|}{ Salt watershed } \\
\hline Jan & 82.0 & 81.4 & 151.8 & 171.6 & 0.87 & 0.92 & 40.7 \\
\hline Feb & 100.6 & 97.3 & 141.4 & 130.6 & 0.84 & 0.91 & 43.7 \\
\hline Mar & 150.2 & 151.0 & 154.1 & 144.4 & 0.90 & 0.94 & 44.6 \\
\hline Apr & 145.7 & 143.9 & 128.7 & 111.6 & 0.91 & 0.95 & 35.3 \\
\hline May & 81.3 & 76.5 & 77.4 & 74.8 & 0.90 & 0.95 & 19.4 \\
\hline Jun & 41.3 & 26.1 & 40.3 & 21.0 & 0.92 & 0.82 & 17.8 \\
\hline Jul & 25.2 & 24.4 & 22.4 & 27.1 & 0.43 & 0.61 & 15.0 \\
\hline Aug & 36.6 & 43.3 & 29.8 & 35.0 & 0.61 & 0.76 & 21.1 \\
\hline Sep & 30.6 & 32.8 & 31.2 & 24.0 & 0.55 & 0.71 & 18.5 \\
\hline Oct & 24.0 & 31.9 & 61.4 & 54.0 & 0.84 & 0.90 & 20.2 \\
\hline Nov & 24.2 & 27.7 & 39.7 & 25.9 & 0.75 & 0.82 & 18.6 \\
\hline Dec & 58.0 & 55.9 & 110.4 & 88.5 & 0.88 & 0.92 & 29.0 \\
\hline Annual & 799.4 & 792.0 & 679.1 & 553.0 & 0.94 & 0.96 & 171.8 \\
\hline \multicolumn{8}{|c|}{ Verde watershed } \\
\hline Jan & 57.6 & 66.8 & 126.8 & 131.0 & 0.95 & 0.97 & 27.3 \\
\hline Feb & 94.7 & 86.1 & 174.7 & 140.7 & 0.91 & 0.94 & 39.0 \\
\hline Mar & 121.9 & 112.6 & 163.4 & 129.0 & 0.80 & 0.87 & 53.0 \\
\hline Apr & 92.1 & 59.7 & 121.1 & 73.1 & 0.78 & 0.81 & 49.6 \\
\hline May & 47.0 & 15.9 & 61.9 & 12.2 & 0.71 & 0.52 & 37.5 \\
\hline Jun & 23.6 & 9.4 & 31.0 & 3.3 & 0.38 & 0.40 & 20.1 \\
\hline Jul & 12.0 & 13.0 & 15.5 & 5.7 & -0.06 & 0.23 & 13.1 \\
\hline Aug & 10.5 & 24.0 & 11.8 & 16.8 & 0.18 & 0.39 & 18.3 \\
\hline Sep & 7.5 & 20.4 & 11.3 & 15.3 & 0.61 & 0.63 & 13.7 \\
\hline Oct & 11.6 & 23.9 & 46.1 & 40.3 & 0.94 & 0.95 & 15.7 \\
\hline Nov & 18.5 & 27.0 & 30.7 & 22.0 & 0.83 & 0.86 & 14.7 \\
\hline Dec & 35.5 & 53.6 & 72.3 & 72.8 & 0.81 & 0.88 & 27.7 \\
\hline Annual & 532.3 & 512.3 & 646.7 & 370.5 & 0.96 & 0.90 & 206.7 \\
\hline
\end{tabular}

difficult to represent the greater intensity of summertime convective precipitation events, during which there is less infiltration and greater overland flow (and eventually runoff) than with winter events.

Model evaluation statistics (Table 3) indicate reasonable co-variability (correlation) and agreement (index of agreement) throughout the year except at the start of monsoon season (July) on each watershed and for the entire summer season of June through August on the Verde watershed. On an annual basis, the water budget model represents too much runoff on the Verde watershed, where the variability in predicted runoff is $>1.5$ times the actual amount of variability (Table 3). Still, correlation coefficients and index of agreement values for annual runoff on the 2 watersheds are very high, and mean absolute error values for annual runoff are 22 and $40 \%$ of the observed annual runoff on the Salt and Verde watersheds, respectively. The amount of systematic error in the water budget model (not shown) suggests that statistical tuning of predicted data to observed data could improve model perfor- mance, but we wished to preserve the basic physical relationships that the model represents as we try to isolate the impacts of temperature and precipitation changes.

\section{SCENARIOS AND GCM OUTPUTS}

In 2000, the IPCC generated a document entitled 'Special report on emissions scenarios' (Nakicenovic \& Swart 2000 ) that is commonly referred to as SRES. Within the document, IPCC scientists describe 4 families of storylines or scenarios of the future, and they provide estimates of how those storylines would impact emissions of a variety of gases into the atmosphere, but they do not affix any likelihood probabilities to the scenarios.

The A1 family of storylines describes a future world of very rapid economic growth, low population growth, and the rapid introduction of new and more efficient technologies. Major underlying themes are convergence among regions, capacity building, and increased cultural and social interactions, with a substantial reduction in regional differences in per capita income. The A2 storylines describe a more heterogeneous world, with an underlying theme of self-reliance and preservation of local identities. Demographic fertility patterns across regions converge very slowly, which results in higher population growth. Economic development is primarily regionally oriented, and per capita economic growth and technological change is more fragmented and slower than in other storylines.

The B1 storylines describe a convergent world with the same low population growth as in the A1 storylines, but with rapid changes in economic structures toward a service and information economy, with reductions in material intensity, and the introduction of clean and resource-efficient technologies. The emphasis is on global solutions to economic, social, and environmental sustainability, including improved equity, but without additional climate initiatives. The B2 storylines describe a world in which the emphasis is on local solutions to economic, social, and environmental sustainability. It is a world with moderate population growth, intermediate levels of economic development, and less rapid and more diverse technological change than in the B1 and A1 storylines. 
By 2050, the total cumulative $\mathrm{CO}_{2}$ accumulation in the atmosphere ranges from near $1000 \mathrm{GtC}$ for the most extreme A1 storylines to near $500 \mathrm{GtC}$ for the various B1 storylines. Nonetheless, the estimated concentration of $\mathrm{CO}_{2}$ by 2050 varies from 600 ppm for the A1 storylines to approximately $450 \mathrm{ppm}$ for the B1 storylines.

Along with the array of storylines, SRES implemented climate models from throughout the world to investigate how the various emission patterns will impact regional, hemispheric, and global climate parameters. The IPCC maintains a website entitled 'The Data Distribution Centre' where the outputs from the various models are available, and, at present, the data are available for 6 different models. These include the Japanese CCSR/NIES coupled ocean-atmosphere model (Emori et al. 1999), the Canadian Global Coupled Model CGCM2 (Flato \& Boer 2001), the Australian CSIRO-Mk2 climate model (Gordon \& O'Farrell 1996), the German ECHAM4 coupled ocean-atmospheric climate model (Roeckner et al. 1996), the United States GFDL R30 climate model (Delworth et al. 2002), and the United Kingdom's HadCM3 climate model (Gordon et al. 2000).

The models differ significantly in terms of basic physical and dynamical design, spatial resolution, and number of atmospheric and oceanic layers. As seen in Fig. 5, multiple grid cells from each model are required to cover the entire Salt and Verde drainage basins. It may be argued that low-resolution GCMs do a poor job of representing climate conditions in the Southwest due to the micro-scale patterns of temperature and precipitation generated by the complex topography in the region (Morehouse 2000). Furthermore, the fourth assessment report of the IPCC (2007, p. 849) states: 'For some regions, there are grounds for stating that the projected precipitation changes are likely or very likely. For other regions, confidence in the projected change remains weak.' The southwestern United States is a region where there is reasonable faith in the prediction of less precipitation by late in the 21 st century; however, we are working at a sub-regional scale, and we are certainly alert to the limitations of downscaling GCM output to our study area.

We downloaded the change in monthly climatological means of temperature $(\Delta T)$ and precipitation $(\Delta P)$, defined as the difference between the means for the $30 \mathrm{yr}$ periods 1961 to 1990 and 2040 to 2069, the latter of which we refer to as the middle of the $21 \mathrm{st}$ century, or year 2050. We downloaded these data for the grid cells containing the study area for all model and scenario combinations for which the data were available from the IPCC website. We were able to gather $\Delta T$ for our study area for 20 different modelscenario combinations, but $\Delta P$ outputs for 1 combination (ECHAM-A2) were unavailable, leaving us with
19 full climate change situations (see Fig. 5 for combinations).

We chose a statistical approach to downscale the model output to our specific study area. Using the Climate Division temperature and precipitation data from the National Climatic Data Center (Karl et al. 1990, Guttman \& Quayle 1996), we determined a time series of temperature and precipitation values from 1895 to 2005 for the combined Salt and Verde drainage basins. We next used the climate divisional data to develop a comparable time series of temperature and precipitation values for the area covered by the climate model grid cells containing the watersheds.

Using simple regression analysis for temperature, the equation becomes $T_{\text {S\&V }}^{\prime}=a+b T_{\text {grid cells, }}$ where $T^{\prime}$ S\&V represents the estimated temperature values for the Salt and Verde, $a$ is the intercept, $T_{\text {grid cells }}$ are the temperature values for the areas of the climate model grid cells, and $b$ is the regression slope equal to $\Delta T_{\mathrm{S} \& \mathrm{~V}} / \Delta T_{\text {grid cells. }}$. For annual temperature, the $b$ values ranged from 0.96 for the HadCM3 model to 1.11 for the CCSR/NIES grid area (Table 5). We repeated this procedure for precipitation and found $b$ values ranging from 1.21 for the CSIRO-Mk2 model to 1.57 for the CCSR/NIES model. The results basically show that changes in temperature in our study area have been similar to regional temperature changes, but variations in precipitation through time in the study area have tended to be larger than the regional-scale variations in rainfall. The range of $b$ values was similar when we conducted the analyses at the monthly timescale. The temperature and precipitation $b$ values associated with each climate model were then applied to the regional $\Delta T$ and $\Delta P$ values generated by each model, and the resulting downscaled $\Delta T$ and $\Delta P$ values for the watersheds were universally applied to all of the grid cells across the Salt and Verde watersheds.

\section{RESULTS AND DISCUSSION}

For each model and scenario combination, we downscaled each monthly value of $\Delta T$ and $\Delta P$ and then applied a 3 mo smoothing to the monthly values. We decided to use the smoothing having noticed that many of the models produce highly unstable changes in precipitation from one month to the next. In many model-scenario combinations, the raw $\Delta P$ values had little to no persistence and would often be positive one month, negative the next, and positive the following month. In the end, we conducted the analyses with the statistical downscaling with no smoothing, downscaling with smoothing, and no downscaling whatsoever, and our results regarding the flow in the Salt and Verde were not impacted in any meaningful way. 


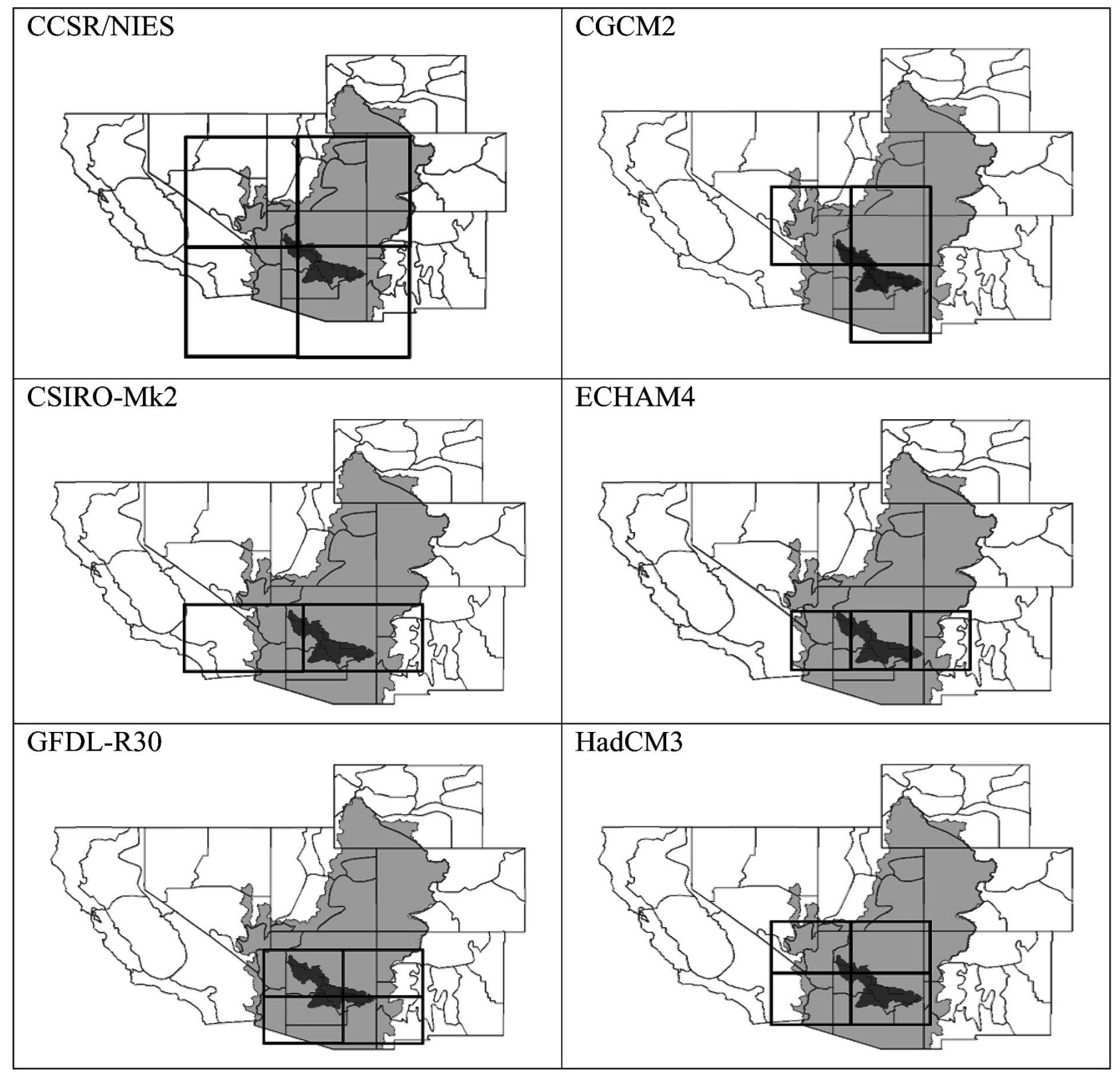

Fig. 5. Area of the Salt and Verde watersheds in relation to the area of the associated grid cells of the various climate models. Dark grey: Salt and Verde watersheds; light grey: Colorado basin. The areal units within the states are climate divisions. Boxes show the grid cells from each model that contain the Salt and Verde. For origin of climate models, see Section 5

Table 5. Downscaling regression coefficients $(b)$ and correlation coefficients (r) for temperature $(T)$ and precipitation $(P)$. For origin of climate models see Section 5

\begin{tabular}{|lcccc|}
\hline Model & $b_{T}$ & $\mathrm{r}_{T}$ & $b_{P}$ & $\mathrm{r}_{P}$ \\
\hline CCSR/NIES & 1.11 & 0.91 & 1.57 & 0.90 \\
CGCM2 & 1.03 & 0.97 & 1.27 & 0.97 \\
CSIRO-Mk2 & 1.02 & 0.96 & 1.21 & 0.96 \\
ECHAM4 & 0.98 & 0.98 & 1.30 & 0.98 \\
GFDL-R30 & 1.07 & 0.99 & 1.34 & 0.98 \\
HadCM3 & 0.96 & 0.97 & 1.30 & 0.98 \\
\hline
\end{tabular}

The annualized $\Delta T$ and $\Delta P$ values show that all models simulate a warmer Salt and Verde drainage area by 2050, irrespective of the scenario selected (Fig. 6), which agrees with the general consensus for the Southwest (IPCC 2007). The $\Delta T$ values range from 2.4 to $5.6^{\circ} \mathrm{C}$ and average $3.7^{\circ} \mathrm{C}$. However, as seen in that same figure, the models vary considerably in the $\Delta P$ values for $\sim 2050$, ranging from -0.6 to $+0.3 \mathrm{~mm} \mathrm{~d}^{-1}$ and averaging $-0.1 \mathrm{~mm} \mathrm{~d}^{-1}$. It is noteworthy that over the most recent $30 \mathrm{yr}$, the study area has witnessed a statistically significant $(\rho<0.01)$ increase in temperature 

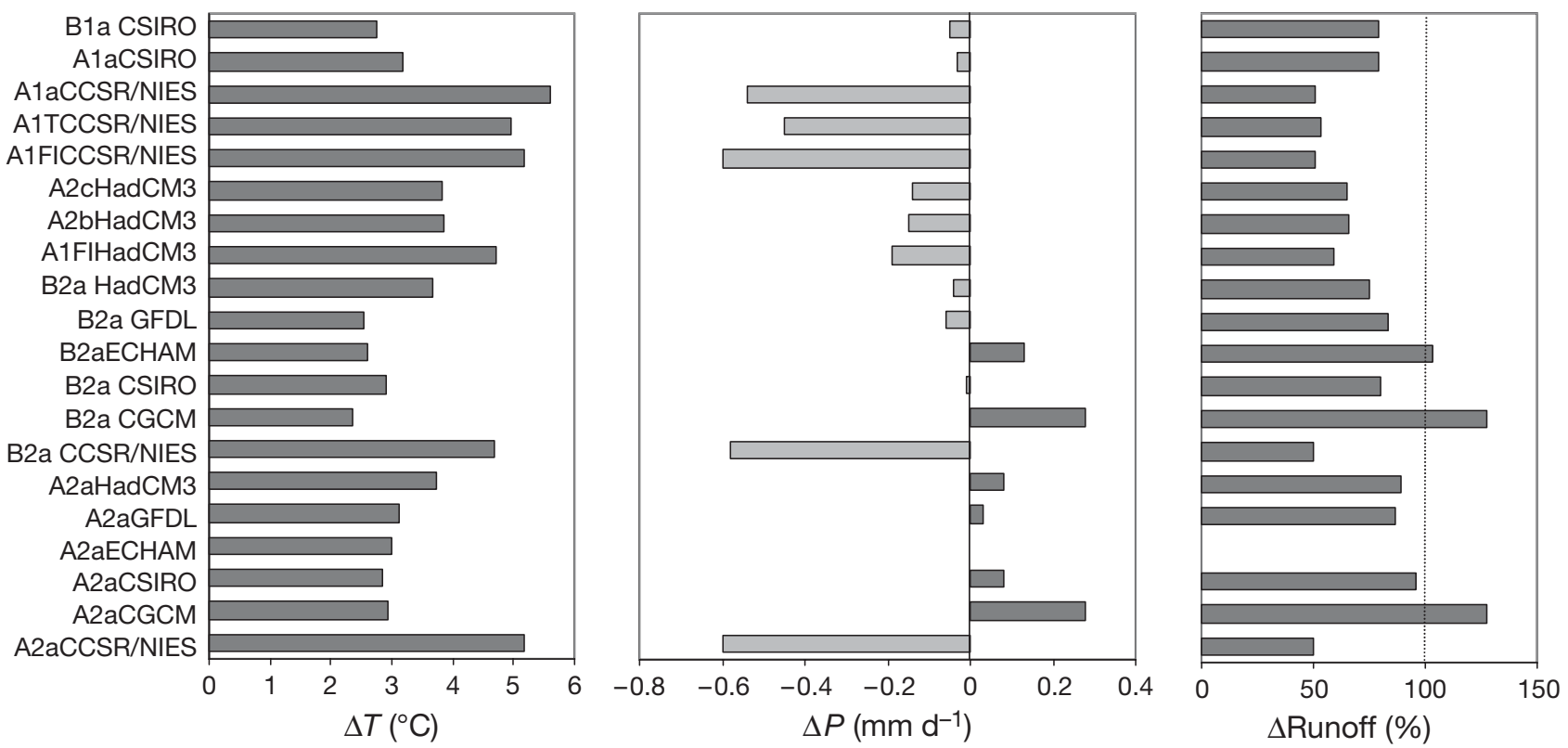

Fig. 6. Approximate 2050 change in temperature $(\Delta T)$, change in precipitation $(\Delta P)$, and change in runoff (\% of historical levels) according to the 20 model-scenario combinations (see Section 5 for further details)

of $0.61^{\circ} \mathrm{C}$ decade ${ }^{-1}$, which is consistent with model predictions for the coming decades. No significant trend exists in the precipitation in the study area over the 3 most recent decades.

We used the monthly values of $\Delta T$ and $\Delta P$ (1961 to 1990 versus 2040 to 2069 ) and re-ran the runoff model over the period 1895 to 2005, but with the changes made to the monthly temperature and precipitation values. As seen in Fig. 6, only 3 of the 19 modelscenario combinations showed an increase in runoff, while the other 16 showed a decrease (ECHAM had no $\Delta P$ values available). The mean for all 19 simulations is $77.4 \%$ of historical runoff levels, with a standard deviation (SD) of $24.0 \%$. We tested this array of 19 values for normality using the standardized indices of skewness and kurtosis as well as the KolmogorovSmirnov test for normality. None of these tests revealed any significant deviation from normality in the array of 19 values.

Therefore, assuming a normal distribution and making the idealistic assumption that all model runs are independent of one another, $68 \%$ of the values should fall between +1 or -1 SD of the mean. Accordingly, we find that there is approximately a 15\% chance that runoff in the Salt and Verde systems will be at or above historical levels by $\sim 2050$. Similarly, there is approximately a $15 \%$ chance that mean runoff by $\sim 2050$ will be only half of the runoff experienced during the past century.

Our results compare favorably with the findings of previous research in which hydrological models were used. Of the 6 climate change-runoff studies in the past 25 yr mentioned previously, the 2 that employed statistical regression techniques produced very large decreases in runoff within the CRB. Revelle \& Waggoner (1983) calculated a reduction in runoff from the Upper Basin of approximately $40 \%$ when applying a temperature increase of $2^{\circ} \mathrm{C}$ and a precipitation decrease of $10 \%$. Also for the Upper Basin, Hoerling \& Eischeid (2007) calculated a $45 \%$ reduction in runoff from a temperature increase of $2.8^{\circ} \mathrm{C}$ and virtually no change in precipitation. However, studies combining emission scenarios, GCM output, and a hydrologic model produced more conservative reductions in runoff. Nash \& Gleick $(1991,1993)$ calculated an approximate $20 \%$ reduction in runoff from the Upper Basin using a temperature increase of $2^{\circ} \mathrm{C}$ and a precipitation decrease of $10 \%$. Christensen et al. (2004) calculated a $17 \%$ reduction in total CRB runoff using a temperature increase of $2^{\circ} \mathrm{C}$ and $3 \%$ decrease in precipitation. Most recently, Christensen \& Lettenmaier (2006) calculated an $11 \%$ reduction in total CRB runoff using a mean temperature increase of $4.35^{\circ} \mathrm{C}$ and a precipitation decrease of $2 \%$.

Although there is reasonable certainty among climate models that precipitation in the southwestern United States will decline by late in the 21st century, we recognize the weaker confidence in precipitation projections than for temperature projections in the fourth assessment report of the IPCC (IPCC 2007). Therefore, we repeated our climate change analyses using the water budget model and GCM-scenario 
combinations, but only applied $\Delta T$ in the simulations. The runoff model results showed a mean of $78.4 \%$ for 20 model-scenario combinations, with a SD of $3.4 \%$. The hydrological result varied little from model to model and from scenario to scenario, the result is based on $\Delta T$ values that are consistent with warming observed over the past 3 decades, and the hydrological result is consistent with many previous studies. It is obvious that the temperature increase projection for the $30 \mathrm{yr}$ period centered on 2050 is largely responsible for the certainty of a decrease in runoff, while the disparate precipitation projections are responsible for elevating uncertainty. If we assume that warming will continue into the future, it appears almost certain that runoff will decrease in the absence of some compensating increase in precipitation.

\section{CONCLUSIONS}

Our results strongly suggest that the runoff of the Salt and Verde systems will very likely decrease in the coming decades. We found that the certainty of a projected decrease in runoff is almost entirely related to the simulated rise in temperature over the coming decades. While the models produced a temperature rise under all scenarios, vastly different estimates of future precipitation changes elevated the uncertainty of the estimates. It is noteworthy that, while the precipitation changes are highly uncertain, all modelscenario combinations suggest a significant increase in temperature, and, over the past 3 decades, temperatures in the Salt and Verde have increased at a rate of $0.7^{\circ} \mathrm{C}$ decade $^{-1}$; if this rate continues linearly, this would lead to a warming of $+3.5^{\circ} \mathrm{C}$ by 2050 (recall that the average for all 20 model-scenario combinations was $+3.7^{\circ} \mathrm{C}$ ). However, it is important to note that projected temperature changes nearer the end of the 21st century are less certain than those at mid-century, simply because it is unclear which of the emission scenario pathways human societies will choose.

There is surprisingly little concern in central Arizona - either among critical decision makers or the public at large - about the region's capacity to supply water for future growth (Morehouse 2000). This attitude stems from the region's historical ability to deal with climatic variability through effective water infrastructure development and management, through the import of water from faraway locations, and through the conversion of water from agricultural to urban uses as large-scale urbanization unfolded. As the region prepares to double in size from 4 million residents today to 8 million in 2040, it faces stiff competition for any additional water supplies from other western water users, and its agricultural buffer is rapidly being depleted. The results of this study suggest that there is substantial uncertainty about the ability of the Salt and Verde watersheds to deliver runoff in amounts consistent with those of the past $100 \mathrm{yr}$. To continue to grow and reconcile increased demand and with possibly decreased supply, water managers and state water policy makers will need to consider policy options ranging from urban planning and design features, landscape treatments, and the use of recycled water to conservation programs and pricing strategies. The results of this study should be a wake-up call that the strategies that served growth during the last $100 \mathrm{yr}$ may not sustain growth for the next $100 \mathrm{yr}$.

Acknowledgements. This material was based upon work supported by the National Science Foundation under Grant No. SES-0345945 Decision Center for a Desert City (DCDC). Any opinions, findings, conclusions, or recommendations expressed in this material are those of the authors and do not necessarily reflect the views of the National Science Foundation.

\section{LITERATURE CITED}

Allen RG, Pereira LS, Raes D, Smith M (1998) Crop evapotranspiration. FAO Irrigation and Drainage Paper 56, Food and Agriculture Organization of the United Nations, Rome

Arizona Department of Economic Security (2006) Arizona population projections 2006 to 2055. Available at www. workforce.az.gov/?PAGEID=67SUBID=138

Blaney HF, Criddle WD (1950) A method of estimating water requirements in irrigated areas from climatological data. Tech Paper 96, USDA, Soil Conservation Service, Washington, DC

Christensen NS, Lettenmaier DP (2006) A multimodel ensemble approach to assessment of climate change impacts on the hydrology and water resources of the Colorado River basin. Hydrol Earth Syst Sci Discuss 3:3727-3770

Christensen NS, Wood AW, Voison N, Lettenmaier DP, Palmer RN (2004) The effects of climate change on the hydrology and water resources of the Colorado River Basin. Clim Change 62:337-363

Daly C, Neilson P, Phillips DL (1994) A statistical-topographical model for mapping climatological precipitation over mountainous terrain. J Appl Meteorol 33:140-158

Delworth TL, Stouffer RJ, Dixon KW, Spelman MJ and others (2002) Review of simulations of climate variability and change with the GFDL R30 coupled climate model. Clim Dyn 19:555-574

Emori S, Nozawa T, Abe-Ouchi A, Numaguti A, Kimoto M, Nakajima T (1999) Coupled ocean-atmosphere model experiments of future climate change with an explicit representation of sulfate aerosol scattering. J Meteorol Soc Jpn 77:1299-1307

Federer CA, Lash D (1983) BROOK: a hydrologic simulation model for eastern forests. Research Report 19, Water Resources Research Center, University of New Hampshire, Durham, NH

Federer CA, Vörösmarty C, Fekete B (1996) Intercomparison of methods for calculating potential evapotranspiration in regional and global water balance models. Water Resour Res 32:2315-2321

> Flato GM, Boer GJ (2001) Warming asymmetry in climate change simulations. Geophys Res Lett 28:195-198 
Gammage G (1999) Phoenix in perspective: reflections on developing the desert. Herberger Center for Design Excellence, College of Architecture and Environmental Design, Arizona State University, Tempe, AZ

Gober P (2005) Metropolitan phoenix: place making and community building in the desert. University of Pennsylvania Press, Philadelphia, PA

Gordon C, Cooper C, Senior CA, Banks H and others (2000) The simulation of SST, sea ice extents and ocean heat transports in a version of the Hadley Centre coupled model without flux adjustments. Clim Dyn 16:147-168

Guttman NB, Quayle RG (1996) A historical perspective of US climate divisions. Bull Am Meteorol Soc 77:293-303

Hamon WR (1961) Estimating potential evapotranspiration. Proc Am Soc Civ Eng 871:107-120

Hirst AC, Gordon HB, O'Farrell SP (1996) Global warming in a coupled climate model including oceanic eddy-induced advection. Geophys Res Lett 23:3361-3364

Hoerling, M, Eischeid J (2007) Past peak water in the southwest. Southwest Hydrology (January/February) 6:18-19, 35

Huang J, van den Dool H, Georgakakos KP (1996) Analysis of model-calculated soil moisture over the United States (1931-93) and application to long-range temperature forecasts. J Clim 9:1350-1362

IPCC (Intergovernmental Panel on Climate Change ) (2007) Climate change 2007: the physical science basis. In: Solomon S, Qin D, Manning M, Chen Z, Marquis M, Averyt KB, Tignor M, Miller HL (eds) Contribution of Working Group I to the 4th Assessment Report of the Intergovernmental Panel on Climate Change. Cambridge University Press, Cambridge

Jacobs KL, Holway JM (2004) Managing for sustainability in an arid climate: lessons learned from 20 years of groundwater management in Arizona, USA. Hydrogeol J 12:52-65

Karl TR, Williams CN Jr, Quinlan FT (1990) United States historical climatology network ( $\mathrm{HCN})$ serial temperature and precipitation data. NPD-019/R1. Carbon Dioxide Information Analysis Center, Oak Ridge National Laboratory, Oak Ridge, TN

Kharrufa NS (1985) Simplified equation for evapotranspiration in arid regions. Beit Hydrol Sonderh 5(1):39-47

Legates DR, McCabe GJ (2005) A re-evaluation of the average annual global water balance. Phys Geogr 26:467-479

Liang X, Lettenmaier DP, Wood EF, Burges SJ (1994) A simple hydrologically based model of land surface water and energy fluxes for GSMs. J Geophys Res 99:14415-14428

Lu J, Sun G, McNulty SG, Amatya DM (2005) A comparison of six potential evapotranspiration methods for regional use in the southeastern United States. J Am Water Resour Assoc 41:621-633

Mather JR (1978) The climatic water budget in environmental analysis. Lexington Books, Lexington, MA

Editorial responsibility: Robert Davis,

Charlottesville, Virginia, USA
Miller DA, White RA (1998) A conterminous United States multi-layer soil characteristics data set for regional climate and hydrology modeling. Earth Interact 2:1-26

Morehouse BJ (2000) Climate impacts on urban water resources in the Southwest: the importance of context. J Am Water Res Assoc 36:265-277

Nakicenovic N, Swart RE (2000) Special Report on Emissions Scenarios. Cambridge University Press, Cambridge

Nash LL, Gleick P (1991) The sensitivity of streamflow in the Colorado Basin to climatic changes. J Hydrol 125: 221-241

Nash, LL, Gleick P (1993) The Colorado River Basin and climate change: the sensitivity of streamflow and water supply to variations in temperature and precipitation. EPA 230-R-93-009 December, EPA, Policy, Planning, and Evaluation, Washington, DC

Revelle RR, Waggoner PE (1983) Effects of a carbon dioxideinduced climatic change on water supplies in the western United States. In: Changing climate. National Academy of Sciences, National Academy Press, Washington, DC, p 419-432

Roeckner E, Arpe K, Bengtsson L, Christoph M and others (1996) The atmospheric general circulation model ECHAM4: model description and simulation of presentday climate. Report No. 218, Max Planck Institut für Meteorologie, Hamburg

Serreze MC, Clark MP, Armstrong DA, McGinnis DL, Pulwarty RS (1999) Characteristics of the western United States snowpack from snowpack telemetry (SNOTEL) data. Water Resour Res 35:2145-2160

Sun G, McNulty SG, Amatya DM, Skaggs RW, Swift LW, Shepard JP, Riekerk H (2002) A comparison of the hydrology of the coastal forested wetlands and the mountainous uplands in the southern United States. J Hydrogeol 263: 92-104

Thornthwaite CW, Mather JR (1955) The water balance. In: Publications in Climatology, Vol 8. Laboratory of Climatology, Centerton, NJ

Willmott CJ (1982) Some comments on the evaluation of model performance. Bull Am Meteorol Soc 63:1309-1313

Willmott CJ, Rowe CM, Mintz Y (1985) Climatology of the terrestrial seasonal water cycle. Int J Climatol 5:589-606

-Wolock DM, McCabe GJ (1999) Explaining spatial variability in mean annual runoff in the coterminous United States. Clim Res 11:149-159

Wood AW, Lettenmaier DP (2006) A testbed for new seasonal hydrologic forecasting approaches in the western U.S. Bull Am Meteorol Soc 87:1699-1712

Xu CY, Singh VP (2001) Evaluation and generalization of temperature-based methods for calculating evaporation. Hydrol Process 15:305-319

Submitted: December 27, 2006; Accepted: November 27, 2007 Proofs received from author(s): January 29, 2008 